\title{
Supportive Therapy on The Family's Burden and Stress in Caring for Patient with Mental Disorder
}

\author{
Fajar Rinawati and Sucipto \\ Departement of Mental Health Nursing, Nursing Academy of Dharma Husada Kediri, Indonesia \\ *Corresponding author: ukhti_fajr@yahoo.com
}

\begin{abstract}
Background: Severe mental disorder has an impact on the family, the environment, the community, even the government, and the most feel is the family, because the family is the person who lives together with the patients. The main problem in the family is the burden and stress in caring them. Objectives: The purpose of this study is to see the effectiveness of supportive therapy on the family's burden and stress for caring the patient with mental disorder at home. Method: The research design used was quasy-experiment pre-post test with control group. The sample in this study is family who caring the patient with mental disorders at home, that according to the inclusion criteria, with a sample size was 24 respondents. Results: The results showed that supportive therapy effective to reduce the burden and stress felt in the family, with $p$-value $=0.000$. Conclusion: Every family who caring the patient with mental disorder must feel the burden and stress, so it is need to cooperate with the others to reduce it, such as all the family members, the environment, Puskesmas, and the Government.
\end{abstract}

Keyword : Effectiveness, Supportive therapy, Burden, Stress, Family, and Mental disorders

\section{INTRODUCTION}

ODGJ ("Orang dengan Gangguan Jiwa"/person with mental disorder) is a term for patients with mental disorder according to the Mental Health Law No 18 of 2014. ODGJ is a person who experience disturbances in thoughts, behaviors, and feelings that manifest in the form of a set of symptoms and/or changes in meaningful behavior, and cause suffering and obstacles in performing human functions as a human beings (Minister of Law and Human Right, 2014). The impact of ODGJ is not only on patients, but also on families, communities, and the goverment (Minister of Health, 2013). The person most affected by the ODGJ is the family, because the family is the person who lives and cares for the patient (Stuart, 2013).

If one of the family has mental disorders, the family will feel sad, feel pain, confusion in caring, embarassed to face the stigma in society, and embarassed to socialize. This is called the burden of the family (Stuart, 2013). Every problem a person faces is a stressor that will cause stress (Videback, 2011). Every individual is different in face of stress. There are able to face individually, but there is a need for support system when the problem occurs. The familial support can reduce the stressful life change and promote adaptive response (Townsend, 2009). 


\section{METHOD}

The design of this study is quasy-experiment pre-post test with control group, which is to observe the influence of an intervention, ie supportive therapy on family's burden and stress with mental disorder. The sample of this study is the family caring for the patient with mental disorder within Puskesmas Balowerti working area. The sampling method used is purposive sampling with several inclusion criteria, that is 12 respondents. The time of this study is abaout 5 months (Mei-September 2017).

\section{RESULTS AND DISCUSSION}

Characteristics of respondents in this study is:

Table 1: Characteristics of Respondents

\begin{tabular}{|c|c|c|c|c|c|}
\hline \multirow[t]{2}{*}{ No } & \multirow[t]{2}{*}{ Characteristics } & \multicolumn{2}{|c|}{ Intervention Group } & \multicolumn{2}{|c|}{ Control Group } \\
\hline & & $\mathbf{n}$ & $\%$ & $\mathbf{n}$ & $\%$ \\
\hline \multirow[t]{4}{*}{1.} & Age: & & & & \\
\hline & a. Adult & 3 & 25 & 7 & 58.33 \\
\hline & b. Early elderly & 5 & 41.67 & 2 & 16.67 \\
\hline & c. Late elderly & 4 & 33.33 & 3 & 25 \\
\hline \multirow[t]{3}{*}{2.} & Sex: & & & & \\
\hline & a. Male & 2 & 16.67 & 3 & 25 \\
\hline & b. Female & 10 & 83.33 & 9 & 75 \\
\hline \multirow[t]{5}{*}{3.} & Education: & & & & \\
\hline & a. Elementary & 5 & 41.67 & 6 & 50 \\
\hline & b. Junior high school & 2 & 16.67 & 1 & 8.33 \\
\hline & c. Senior high school & 4 & 33.33 & 4 & 33.33 \\
\hline & d. College & 1 & 8.33 & 1 & 8.33 \\
\hline \multirow[t]{5}{*}{4.} & Work: & & & & \\
\hline & a. Unemployment & 4 & 33.33 & 7 & 58.33 \\
\hline & b. Wiraswasta & 5 & 41.67 & 3 & 25 \\
\hline & c. Swasta & 1 & 8.33 & 0 & 0 \\
\hline & d. Buruh & 2 & 16.67 & 2 & 16.67 \\
\hline \multirow[t]{4}{*}{5.} & Income: & & & & \\
\hline & a. $\leq$ Rp.500.000,- & 9 & 75 & 8 & 66.67 \\
\hline & b. Rp.500.000,- - Rp. 1.000.000,- & 3 & 25 & 3 & 25 \\
\hline & c. $\geq$ Rp.1.000.000,- & 0 & 0 & 1 & 8.33 \\
\hline \multirow[t]{4}{*}{6.} & Married status: & & & & \\
\hline & a. Single & 0 & 0 & 2 & 25 \\
\hline & b. Merried & 11 & 91.67 & 9 & 75 \\
\hline & c. Widow/widower & 1 & 8.33 & 1 & 8.33 \\
\hline \multirow[t]{5}{*}{7.} & Relationship with the patient: & & & & \\
\hline & a. Parents & 4 & 33.33 & 4 & 33.33 \\
\hline & b. Brother/sister & 4 & 33.33 & 2 & 25 \\
\hline & c. Husband/wife & 1 & 8.33 & 1 & 8.33 \\
\hline & d. The others & 3 & 25 & 5 & 41.67 \\
\hline \multirow[t]{4}{*}{8.} & Long sick: & & & & \\
\hline & a. $\leq 1$ year & 0 & 0 & 0 & 0 \\
\hline & b. $1-5$ years & 6 & 50 & 5 & 41.67 \\
\hline & c. $\geq 5$ years & 6 & 50 & 7 & 58.33 \\
\hline
\end{tabular}


Table 2: Family's Burden And Stress

\begin{tabular}{llcccc}
\hline No & Variable & \multicolumn{2}{c}{ Before Intervention } & \multicolumn{2}{c}{ After Intervention } \\
\hline & & Mean & SD & Mean & SD \\
\hline 1. & Burden & 39.92 & 7.24 & 22.08 & 7.05 \\
\hline 2. & Stress & 100.33 & 23.63 & 56.83 & 10.13 \\
\hline
\end{tabular}

Table 3: The Differences of Family's Burden And Stress

\begin{tabular}{llc}
\hline No & \multicolumn{1}{c}{ Variable } & p-value \\
\cline { 1 - 1 } 1. & Burden before intervention & \multirow{2}{*}{0.000} \\
\hline 2. & Burden after intervention & \\
\cline { 1 - 2 } 3. & Stress before intervention & \multirow{2}{*}{0.000} \\
\hline 4. & Stress after intervention & \\
\hline
\end{tabular}

Table 2 and 3 show that there are a significant difference in family's burden and stress between before and after intervention (supportive therapy). Respondents in this study were mostly female $(83,33 \%)$. A woman's job is to take care of the family, so stay at home, while a man's job is looking for income (out of the home). So a lot of care giver that is female. In addition the respondents in this study also showed that many respondents do not have income or income below Ro. 500.000,-.

The burden felt that the family feels are an objective and subjective burden. The objective burden is the visible and the subjective burden is invisible. The visible burden that the family feels such as financial difficulties, confused how to care, hassles in caring, exhausted, fatigue, time limitations. The invisible burden that the family feels such as feelings of sadness, loss, anxiety, worry, distress, and shame. The stres that the family feels such as physical, emotional, and mental stress. Physical stress that the family feels such as difficulty sleeping, headache, appetite changes, body aches, dry mouth and the others. Emotional stress that the family feels such as often angry, sad, hopeless, anxiety, and the others. Mental stress that the family feels such as difficult concentration, difficult to think clearly, difficult to make decisions, and the others.

Supportive therapy is one $\mathrm{f}$ the group therapy that has the purpose to solve common problems. Supportive therapy proven to reduce family's burden and stress due to caring the patient with mental disorder. This therapy makes the members feel not alone, have friends who experience the same thing. This therapy enables the members to share experience about anything, such as how to care the patient, how reduce the stress that they feel, and how reduce the burden too.

\section{CONCLUSION}

Characteristis of families who care ODGJ: the most age is the early alderly, the age is women, the education is elementary school, the most job is wiraswasta, the income is less than Rp. 500.000,-, the marital status is married, the relationship with the patient is the nuclear family (husband/wife and children), and the patient haved been sick for more than one year.

There is a change in the family's burden and stress between before and after intervention. The p-value is $<0.005(0.000)$. It is mean that there is a significant difference, so supportive therapy can reduce the family's burden and stress due to caring the patient. 


\section{ACKNOWLEDGEMENT}

The autors thank to Ristekdikti, Director of Nursing Academy Dharma Husada Kediri, Chief of Puskesmas Balowerti and Campurejo, respondents, and the others who have supported both material and non-material. The authors hope this research can be used as a evidence based in making decision related to mental health nursing, especially for the family that caring the patient. This research can be the evidence based for further research, for example about effectiveness of self help group therapy for the family who caring the patient with mental disorder.

\section{REFERENCES}

Friedman, M.M, (2010), Buku Ajar Keperawatan Keluarga. Riset, Teori dan Praktik. Jakarta: EGC.

Gallin, J.I. \& Ognibene, F.P, (2007), Principles and Practice of Clinical Research. USA: Elsevier.

Hastono, S.P. \& Sabri, L, (2011), Statistik Kesehatan. Jakarta: PT Raja Grafindo Persada.

Kozier, B. et al. (2011). Buku Ajar Fundamental Keperawatan, Konsep, Proses \& Praktik. Jakarta: EGC.

Minister of Health, (2013), Riskesdas 2013. Jakarta

Minister of Law and Human Right. (2014). Mental Health Law No 18 of 2014. Jakarta.

Polit, D.F. \& Beck, C.T. (2012). Nursing Research, Generating and Assessing Evidence for Nursing Practice. Philadelphia: Lippincitt Williams \& Wilkins.

Riduwan. (2010). Metode dan Teknik Menyusun Tesis. Bandung: Alfabeta.

Stuart, G.W. (2013). Principles and Practice of Psychiatric Nursing. 10 ${ }^{\text {th }}$ Ed. Canada: Evolve.

Townsend, M.C. (2009). Psychiatric Mental Health Nursing, Concepts of Care in Evidence-Based Practice. $6^{\text {th }}$ Ed. Philadelphia: Davis Plus.

Varcarolis, E.M. \& Halter, M.J, (2010), Psychiatric Mental Health Nursing, A Clinical Approach. $6^{\text {th }}$ Ed. Canada: Elsevier.

Videback, S.L, (2011), Psychiatric-Mental Health Nursing. $4^{\text {th }}$ Ed. China: Wolters Kluwer. 